\title{
Chemical glycosylation of cytochrome c improves physical and chemical protein stability
}

Yamixa Delgado ${ }^{1}$, Moraima Morales-Cruz ${ }^{1}$, José Hernández-Román ${ }^{1}$, Yashira Martínez ${ }^{1}$ and Kai Griebenow ${ }^{1,2^{*}}$

\begin{abstract}
Background: Cytochrome c (Cyt c) is an apoptosis-initiating protein when released into the cytoplasm of eukaryotic cells and therefore a possible cancer drug candidate. Although proteins have been increasingly important as pharmaceutical agents, their chemical and physical instability during production, storage, and delivery remains a problem. Chemical glycosylation has been devised as a method to increase protein stability and thus enhance their long-lasting bioavailability.

Results: Three different molecular weight glycans (lactose and two dextrans with 1 kD and $10 \mathrm{kD}$ ) were chemically coupled to surface exposed Cyt c lysine (Lys) residues using succinimidyl chemistry via amide bonds. Five neo-glycoconjugates were synthesized, Lac ${ }_{4}-C y t-c$, Lac ${ }_{9}-C y t-c, D_{1} x_{5}(10 k D)-C y t-C, D_{1} x_{8}(10 k D)-C y t-c$, and Dex 3 (1 kD)-Cyt-c. Subsequently, we investigated glycoconjugate structure, activity, and stability. Circular dichroism (CD) spectra demonstrated that Cyt c glycosylation did not cause significant changes to the secondary structure, while high glycosylation levels caused some minor tertiary structure perturbations. Functionality of the Cyt c glycoconjugates was determined by performing cell-free caspase 3 and caspase 9 induction assays and by measuring the peroxidase-like pseudo enzyme activity. The glycoconjugates showed $\geq 94 \%$ residual enzyme activity and $86 \pm 3$ to $95 \pm 1 \%$ relative caspase 3 activation compared to non-modified Cyt c. Caspase 9 activation by the glycoconjugates was with $92 \pm 7 \%$ to $96 \pm 4 \%$ within the error the same as the caspase 3 activation. There were no major changes in Cyt $c$ activity upon glycosylation. Incubation of $\operatorname{Dex}_{3}(1 \mathrm{kD})$-Cyt $\mathrm{c}$ with mercaptoethanol caused significant loss in the tertiary structure and a drop in caspase 3 and 9 activation to only $24 \pm 8 \%$ and $26 \pm 6 \%$, respectively. This demonstrates that tertiary structure intactness of Cyt c was essential for apoptosis induction. Furthermore, glycosylation protected Cyt c from detrimental effects by some stresses (i.e., elevated temperature and humidity) and from proteolytic degradation. In addition, non-modified Cyt c was more susceptible to denaturation by a water-organic solvent interface than its glycoconjugates, important for the formulation in polymers.
\end{abstract}

Conclusion: The results demonstrate that chemical glycosylation is a potentially valuable method to increase Cyt c stability during formulation and storage and potentially during its application after administration.

Keywords: Apoptosis, Chemical glycosylation, Drug delivery, Pharmaceutical protein, Protein formulation, Protein stability

\section{Background}

Development of efficient cancer treatments is a top priority in health related research. One of the most common available options, in particular to treat advanced stages or as post-operation treatment, is chemotherapy which still today mostly employs extremely cytotoxic drugs that kill metabolically active cells. Such drugs include alkylating

\footnotetext{
*Correspondence: kai.griebenow@gmail.com

'Department of Biology, University of Puerto Rico, Río Piedras Campus, P.O. Box 70377, San Juan, Puerto Rico 00931-3346, USA

${ }^{2}$ Department of Chemistry, University of Puerto Rico, Río Piedras Campus, P.O. Box 70377, San Juan, Puerto Rico 00931-3346, USA
}

agents (e.g., cis-platin), anti-metabolites (e.g., 5-fluor uracil, gemcitabine), anti-microtubule agents (e.g., paclitaxel), and topoisomerase inhibitors (e.g., doxorubicin). Unfortunately, all these drugs have low tumor specificity and a frequently narrow therapeutic index thus producing significant unwanted side effects $[1,2]$. This situation has resulted in an intense search for cancer drugs that are more tumor-targeted and less toxic to normal cells [3-11]. As the result, a set of tumor-targeted nanomedicines is currently being studied that exploit hallmarks of cancer for reviews see references [12-14]. Targeting mechanisms include coupling of cytotoxic 
agents to ligands, antibodies, analogs targeting overexpressed receptors, formulation as nanoparticles to exploit the enhanced permeability and retention (EPR) effect, drugs specifically targeting enzymes involved in ontogenesis, among others [15-20]. Drug molecules involved in this area include small molecules, peptides, proteins, RNA molecules, and even complete oncolytic viruses [21-23].

Proteins are a potentially attractive class of drugs because they can be used to exploit the hallmarks of cancer by targeting specific events. One hallmark is that in cancer cells, particularly cancer stem cells, apoptosis is frequently disabled $[22,24]$. Delivery of a molecule to the cell switching apoptosis back on is therefore a potential treatment strategy. Cyt c is exactly such a molecule. It is a small mitochondrial heme protein involved in the intrinsic apoptotic pathway [24]. Severe DNA damage in cells and other events such as increase in $\mathrm{P}_{53}$, oxidative stress, and hypoxia lead to the activation of the intrinsic apoptotic pathway, which involves formation of pores in the mitochondrial membrane by BAX, BAK, and SMAC $[25,26]$. The BH3-only domain proteins directly bind and activate mitochondrial-localized BAK and BAX, triggering $\mathrm{BAK} / \mathrm{BAX}$ oligomerization and inhibition of BCL-XL proteins $[27,28]$. The resulting depolarization of the mitochondrial membrane induces the release of Cyt c and other apoptotic factors into the cytoplasm [29]. Cyt $c$ then interacts with the protein Apaf- 1 to form the apoptosome [24].

Apoptosis is absent in many cancer cells for multiple reasons including mutation of critically important elements upstream from the event involving Cyt c [30]. Thus, a valid strategy is the delivery of Cyt c directly to the cytosol of cancer cells to induce apoptosis and eradicate the tumor. Using cancer models this has been accomplished multiple times by delivering Cyt $\mathrm{c}$ from nanoparticles [30-32] but it is yet unclear whether such systems would be sufficiently effective to allow for cancer treatment under real conditions. For example, uptake of nanoparticles frequently involves receptor-mediated endocytosis and thus the protein is exposed to conditions of low $\mathrm{pH}$ and proteases in lysosomes prior to the necessary endosomal escape [33-35]. Furthermore, the interstitium of tumors is frequently rich in proteases that are detrimental to pharmaceutical proteins [12,36].

In addition to aforementioned specific reasons, development of effective protein formulations is a significant challenge in the biopharmaceutical industry due to the inherent chemical and physical instability of proteins during production and purification [37], formulation [38], storage [39,40], transportation $[39,41]$, and administration [42]. Particularly challenging is the development of smart drug-delivery and release systems for protein drugs in this context, because they typically rely on immobilization of the drug in the carrier $[43,44]$. The immobilization frequently employs linkers with $\mathrm{pH}$ - or redox-sensitive bonds that are cleaved in the cell but many proteins are structurally sensitive to the linker attachment, as we have demonstrated recently for carbonic anhydrase [45] and also for Cyt c [46].

Improving the stability of pharmaceutical proteins under the many different aforementioned circumstances, in particular during delivery, likely requires covalent strategies. One current example of such strategies consists in modifying FDA approved protein drugs with poly(ethylene glycol) (PEG) to afford increased plasma life time and reduced immunogenicity $[16,47]$. However, PEGs have not been reported to significantly stabilize proteins thermodynamically [48]. Also, PEGs are not biodegradable and can in tendency accumulate in the body [49]. A possible biodegradable alternative to modification of proteins with PEG is the covalent modification with carbohydrates. Chemical as opposed to natural glycosylation has recently been used as a strategy to stabilize commercially available medicines (i.e., glycosylated erythropoietin alfa (ARANESP ${ }^{\oplus}$ ) and glycosylated brain natriuretic peptide (NATRECOR ${ }^{\circ}$ ) [50,51].

We have in recent years introduced chemical modification to stabilize several model proteins. We have systematically investigated the structure, function, dynamics, and stability interrelationships in the neo-glycoconjugates obtained [52-56]. We found that glycosylation of many model proteins provides the advantages typically associated with PEGylation but we also found significantly increased thermodynamic stability [57]. In this work we set out to investigate in more detail the stability, functional, and structural consequences of chemical protein glycosylation using for the first time a cancer relevant pharmaceutical protein, namely, Cyt c. We are able to demonstrate that chemical glycosylation is a potentially very useful method to stabilize Cyt $\mathrm{c}$ in pharmaceutical applications.

\section{Results and Discussion}

Our strategy was to attach sugars via suitable linker chemistry to the $\varepsilon$-amino groups of lysine residues of Cyt c to establish various glycoconjugates. In order to vary the glycan size in our experiments, we chose dextran with molecular weights of $1 \mathrm{kD}$ and $10 \mathrm{kD}$ and lactose $(0.5 \mathrm{kD})$ as glycans. The $10 \mathrm{kD}$ dextran was first activated by reductive amination followed by modification with a homo-bifunctional linker to form amine reactive mono(dextranamido)-mono-(succinimidyl)suberate (NHS-Dex, $10 \mathrm{kD})$ as described by us [52-55]. However, this did not work for the small dextran because the precipitation step failed. Thus, we used established 1-ethyl-3-[3-dimethylaminopropyl]carbodiimide hydrochloride (EDC)/N-hydroxysuccinimide (NHS) crosslinking chemistry with dextran hexanoic acid (Dex-COOH) to form NHS-Dex (1 kD). 
Activated lactose (NHS-Lac) is commercially available and was used as supplied. The amine and succinimidyl functionalization of the dextrans was followed by FTIR and NMR spectroscopy as described by us [52-55]. The activated sugars were then coupled to available amines of Cyt c (Figure 1) as previously described by us for various proteins $[46,52-56]$.

The neo-glycoconjugates obtained were characterized (Table 1). Five different conjugates were obtained with the three different glycans. Throughout the manuscript we adopt the following nomenclature: Cyt $\mathrm{c}$ modified at 4 and 9 lysine residues with lactose was named $\mathrm{Lac}_{4}$-Cyt $\mathrm{c}$ and $\mathrm{Lac}_{9}$-Cyt c; Cyt $\mathrm{c}$ modified at 5 and 8 lysine residues with dextran of $10 \mathrm{kD}$ were named $\operatorname{Dex}_{5}(10 \mathrm{kD})$ Cyt $\mathrm{c}$ and $\operatorname{Dex}_{8}(10 \mathrm{kD})$-Cyt c; and the glycoconjugate with 3 lysine residues modified with dextran of $1 \mathrm{kD}$ was named $\operatorname{Dex}_{3}(1 \mathrm{kD})$-Cyt c. Glycosylation did not affect the pseudo-enzyme activity even for the most heavily glycosylated sample $\left(\operatorname{Dex}_{8}(10 \mathrm{kD})\right.$-Cyt $\left.\mathrm{c}\right)$ in which there was a total of $80 \mathrm{kD}$ of glycan attached to the roughly 13 $\mathrm{kD}$ protein. We can surmise that structure of Cyt c was likely not affected by binding of the sugars and that the substrate could still relatively freely diffuse to the active site even in the presence of a "sugar shell".

The use of Cyt $\mathrm{c}$ as an anti-cancer drug depends on the formation of the Apaf-1/Cyt c complex (apoptosome), which is responsible for the activation of the caspase cascade leading to apoptosis. Electrostatic interactions between positively charged lysine residues of Cyt $\mathrm{c}$ at the exposed heme edge and the WD-40 region of Apaf- 1 are critically important to facilitate Cyt c-to-Apaf-1 binding $[58,59]$. Thus, it is imperative to preserve the Cyt c conformation subsequent to any chemical modification to assure that Cyt c is still able to bind to Apaf- 1 and induce apoptosis. We performed a cell-free caspase 3 and 9 assays since Cyt $\mathrm{c}$ is a cell-membrane impermeable protein $[30,31,60]$. After the freeze and thaw cycles the lysate was centrifuged at 10,000 g to ensure mitochondrial removal. This is important to avoid false positives from mitochondrial leakage of Cyt c. Furthermore, we added the substrates to the lysates as controls and subtracted any small absorbance developing from the samples to which the external Cyt c or Cyt c glycoconjugates was added. The data obtained (Table 1) show that at most levels of glycosylation the bioactivity of Cyt c was still ca. 90\% compared to non-modified Cyt c. This result is in thus far remarkable as there are lysine residues in the putative Cyt-c-Apaf-1 binding epitope. We have reported a similar finding albeit with $\mathrm{Lac}_{4}$-Cyt $\mathrm{c}$ and Cyt c-Lac ${ }_{4}$-SPDP for Cyt c activity on HeLa cells [46].

There are several potential explanations for this that need to be verified by site-directed glycosylation (currently ongoing in our laboratory). First, glycosylation could be inefficient for Lys residues in the Apaf- 1 interaction epitope. We have highlighted why we believe this is happening in Additional file 1. Second, glycosylation could make Cyt c intrinsically more reactive and this could compensate for activity loss by glycosylation of residues in the interaction epitope. Third, glycosylation might not prevent Cyt c binding to Apaf 1 because ionic interactions are long-range. Regardless of the mechanistic reason, however, even highly glycosylated Cyt c was still remarkably active in activating the caspase cascade.

To investigate the structural consequences of glycan binding to Cyt c, we performed circular dichroism (CD) spectroscopy. Three spectral regions were investigated: the far-UV CD region from $200-280 \mathrm{~nm}$ which is sensitive to secondary structural perturbations, the near UVCD region from $260-320 \mathrm{~nm}$ which is sensitive to tertiary structure perturbations, and the Soret region of heme absorbance from 380 to $460 \mathrm{~nm}$ which is sensitive to the heme environment and thus the structure of the heme binding pocket (Figure 2). In the far UV-CD region only minor spectral and thus secondary structural
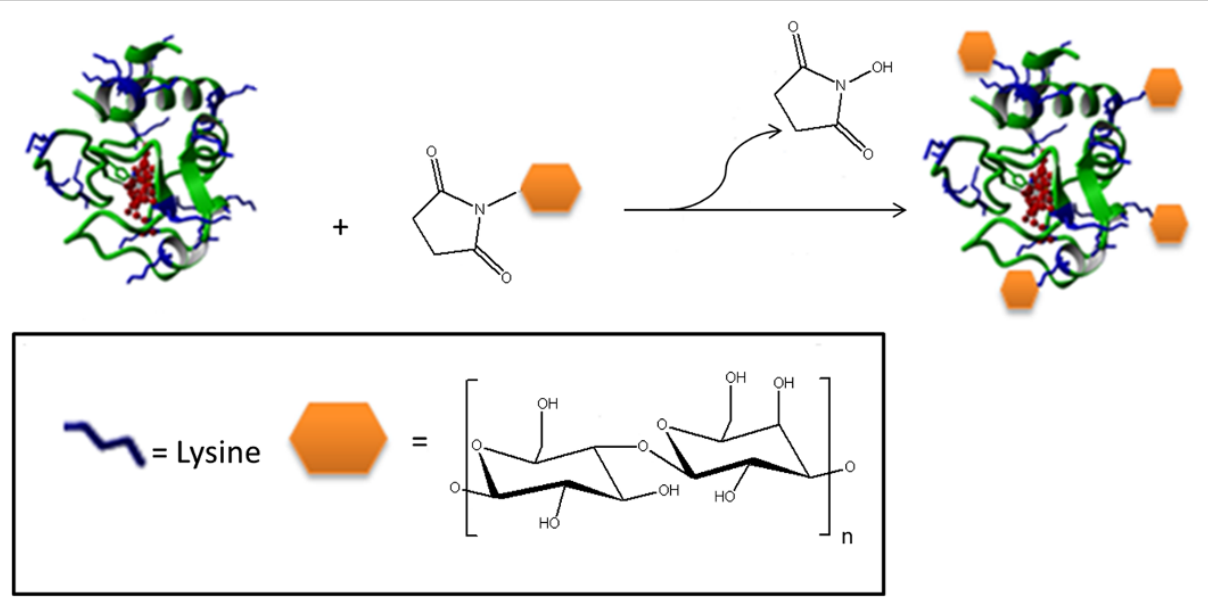

Figure 1 Representation of the chemical glycosylation of Cyt c using monofunctionally activated glycans. 
Table 1 Functionality determination for Cyt c glycoconjugates

\begin{tabular}{|c|c|c|c|c|c|}
\hline $\begin{array}{l}\text { Protein } \\
\text { formulation }\end{array}$ & Glycosylation degree $^{\#}$ & Residual activity $\$$ (\%) & Caspase 3 activation ${ }^{\%}(\%)$ & Caspase 9 activation $\%$ (\%) & $\begin{array}{l}\text { Degradation rate, } \\
\mathrm{K}_{\mathrm{d}}^{\&}\left(\mathrm{x} 10^{-2} \mathrm{~min}^{-1}\right)\end{array}$ \\
\hline Cyt c & N/A & 100 & 100 & 100 & $10.3 \pm 0.1$ \\
\hline $\mathrm{LaC}_{4}$-Cyt C & $4.4 \pm 0.4$ & $94 \pm 4$ & $95 \pm 1$ & $95 \pm 9$ & $9.9 \pm 0.2$ \\
\hline $\mathrm{LaC}_{9}-\mathrm{Cyt} \mathrm{C}$ & $9.3 \pm 0.2$ & $97 \pm 2$ & $86 \pm 3$ & $93 \pm 8$ & $9.6 \pm 0.1$ \\
\hline $\operatorname{Dex}_{3}(1 \mathrm{kD})$-Cyt c & $3.4 \pm 0.9$ & $98 \pm 1$ & $91 \pm 2$ & $96 \pm 4$ & $9.8 \pm 0.2$ \\
\hline $\operatorname{Dex}_{5}(10 \mathrm{kD})$-Cyt c & $5.2 \pm 0.8$ & $93 \pm 4$ & $89 \pm 1$ & $94 \pm 6$ & $9.5 \pm 0.1$ \\
\hline $\operatorname{Dex}_{8}(10 \mathrm{kD})-\mathrm{Cyt} \mathrm{c}$ & $8.3 \pm 0.4$ & $95 \pm 3$ & $85 \pm 2$ & $92 \pm 7$ & $9.9 \pm 0.3$ \\
\hline
\end{tabular}

\#Glycosylation degree refers to the number of glycan modified Cyt c lysine residues as determined by 2,4,6-trinitrobenzene sulfonic acid (TNBSA) assay. ${ }^{5}$ The residual activity was calculated with respect to the specific activity of native Cyt c. ${ }^{\%}$ The caspase 3 and caspase 9 activation is with respect to the activation induced by non-modified Cyt c. The substrates used for caspase-3 and caspase- 9 activation assay were 10 mM DEVD-pNA and 4 mM LEHD-pNA, respectively. ${ }^{\&}$ The rate of degradation was calculated for Cyt $\mathrm{c}$ and Cyt c glycoconjugates after exposure to $1.5 \mathrm{mM} \mathrm{H}_{2} \mathrm{O}_{2}$. Each experiment was performed in triplicate, the values averaged, and the \pm values are the calculated SD.

changes were observed. In contrast, spectral variations were evident when investigating the glycoconjugates in spectral regions that are sensitive to tertiary structural changes. The near UV-CD spectra of Cyt $\mathrm{c}$ and the lactose glycoconjugates were similar, while the dextran bioconjugates showed a reduced signal, which can be interpreted as being indicative of less tertiary structure (Figure 2B). Nevertheless, the CD spectra in the heme absorption region (Figure $2 \mathrm{C}$ ) all showed a pronounced cotton effect, which is typical for a native heme environment. The Cotton effect, named after its discoverer Aimé Cotton (1869-1951), is the characteristic change in circular dichroism in the vicinity of an absorption band of a substance characterized by a positive and negative CD signal and a zero crossing at the absorption maximum. Structural changes in the heme-binding pocket lead to the disappearance of the cotton effect as reported by others and us for Cyt c $[46,61]$. This is in agreement with the activity data in Table 1, which show that all bioconjugates had a similar pseudo enzyme activity than Cyt c. We can surmise that for all bioconjugates the structure was native-like with the exception of a somewhat more lose tertiary structure packing in case of the dextran conjugates.

Next we proceeded to study the Cyt c stability in selected experiments. Chemical glycosylation has been shown to assist in overcoming chemical protein instability and provide protection against proteases [62-64]. This is highly relevant since it has been established that the tumor interstitial space presents significant trypsinlike protease activity and also oxidative stress [36]. Trypsin-like activity is particularly harmful to the integrity of basic proteins. The proteolytic degradation in tumors enables cell movement and the metastatic spread $[31,65]$. Potential improvement of Cyt c stability towards the tumor environment by glycosylation was tested by tryptic and chymotryptic assays.

The results of the tryptic digestion are shown in Figure 3. As anticipated, trypsin had a devastating effect on Cyt c integrity. Glycosylation stabilized the protein against proteolysis. It is evident that the amount of glycan bound to the protein is more significantly related to protection against proteolysis than the size of the bound glycan. For example, Lac 9 -Cyt $\mathrm{c}$ and $\operatorname{Dex}_{8}(10 \mathrm{kD})$-Cyt $\mathrm{c}$ show similar protection from trypsin degradation even though there is about 20 times more glycan bound per weight in the dextran containing bioconjugate. This can be understood because trypsin cuts the peptide backbone next to Lys or Arg residues and the more Lys residues are chemically blocked, the lower the propensity for the proteolytic event to happen [66].

To obtain a better idea of whether glycans in general protect Cyt c from proteolytic degradation by steric shielding, we also performed digestion with $\alpha$ chymotrypsin, which cuts preferentially next to aromatic residues. We employed those samples for which glycosylation provided the best protection in the tryptic assay (Figure 3). It is evident that glycosylation protected Cyt $\mathrm{c}$ from proteolysis, albeit to a much lesser degree than in the tryptic assay (Figure 4). We can therefore conclude that glycosylation protects Cyt c from proteolytic degradation in general, but much better against those proteases having a binding pocket selective for Lys.

In summary, glycosylation should provide some protection against proteolytic degradation in the tumor interstitium and possibly after endocytosis of suitable constructs in lysosomes in agreement with our recent data using HeLa cells [46].

Cancer tissues frequently display an increased level of reactive oxygen species and oxidative stress as a result of persistent chronic inflammation [67]. The in vivo degradation of proteins by $\mathrm{H}_{2} \mathrm{O}_{2}$ interferes with normal cellular function, accelerates aging, and enhances metabolism of carcinogens $[68,69]$. Higher levels of free radicals also induce DNA mutations, which promote cancer progression and development of resistance [70]. To test whether glycosylation could protect the protein from oxidative stress, 

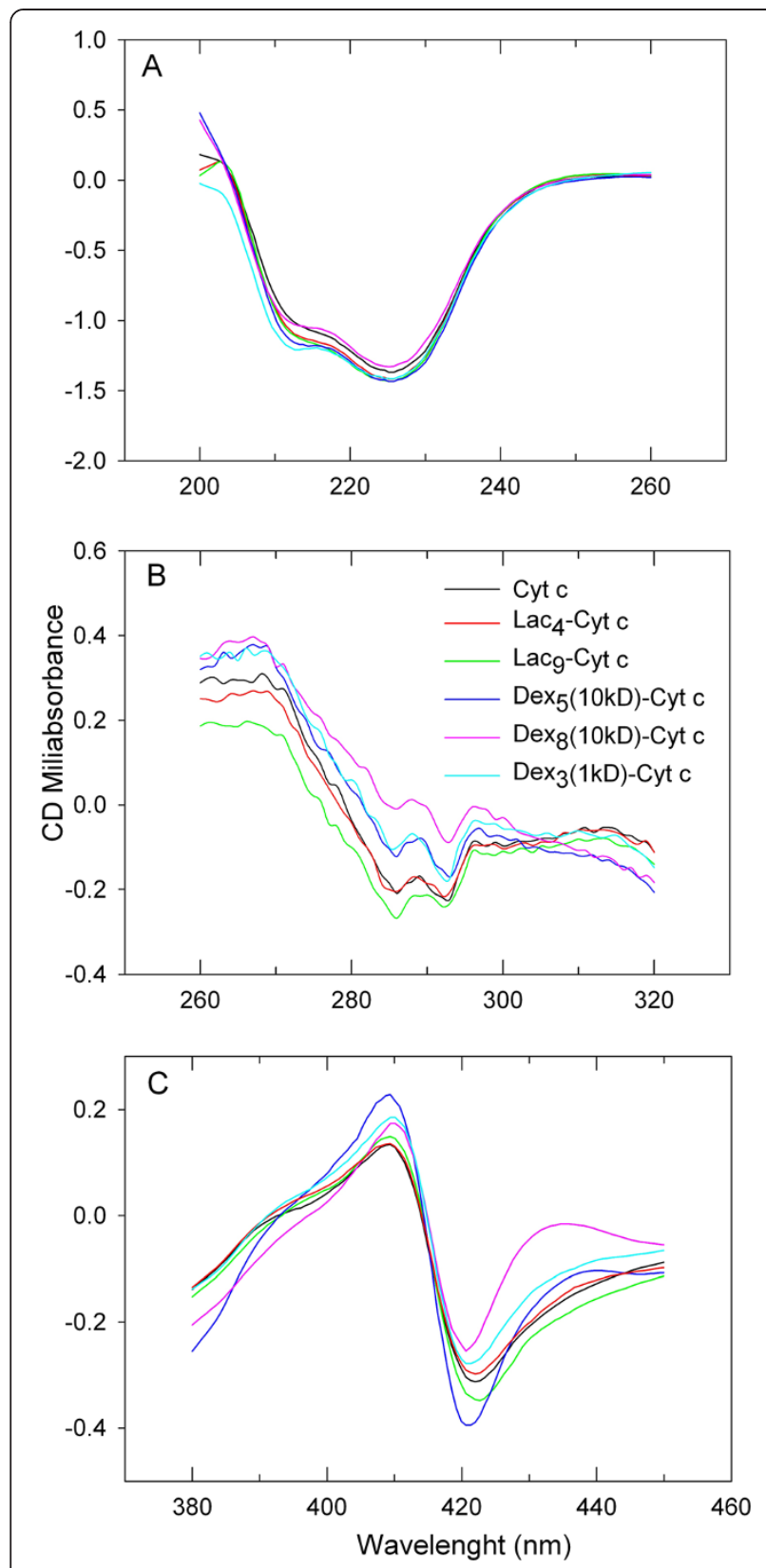

Figure 2 Far UV (A), near UV (B), and heme (C) region CD spectra of $0.6 \mathrm{mg} / \mathrm{ml} \mathrm{Cyt} \mathrm{c}$ and Cyt c glycoconjugates in $100 \mathrm{mM}$ phosphate buffer at $\mathrm{pH} 7.4$ and $20^{\circ} \mathrm{C}$.

Cyt c was incubated with $200 \mu \mathrm{L}$ of $1.5 \mathrm{mM}$ of $\mathrm{H}_{2} \mathrm{O}_{2}$, which attacks the S-S bridge that covalently couples the heme group to apo Cyt $\mathrm{c}$ thus promoting unfolding $[61,71,72]$. The rate of degradation $\left(K_{d}\right)$ was determined from the decaying heme Soret absorbance (Table 1). No significant effect was found in this instance and chemical degradation by Cyt $\mathrm{c}$ with the small molecule $\mathrm{H}_{2} \mathrm{O}_{2}$ was not significantly slowed down. Therefore, it might be of value to protect Cyt $\mathrm{c}$ from the oxidative stress in tumor tissues by packaging it inside a delivery vehicle. The

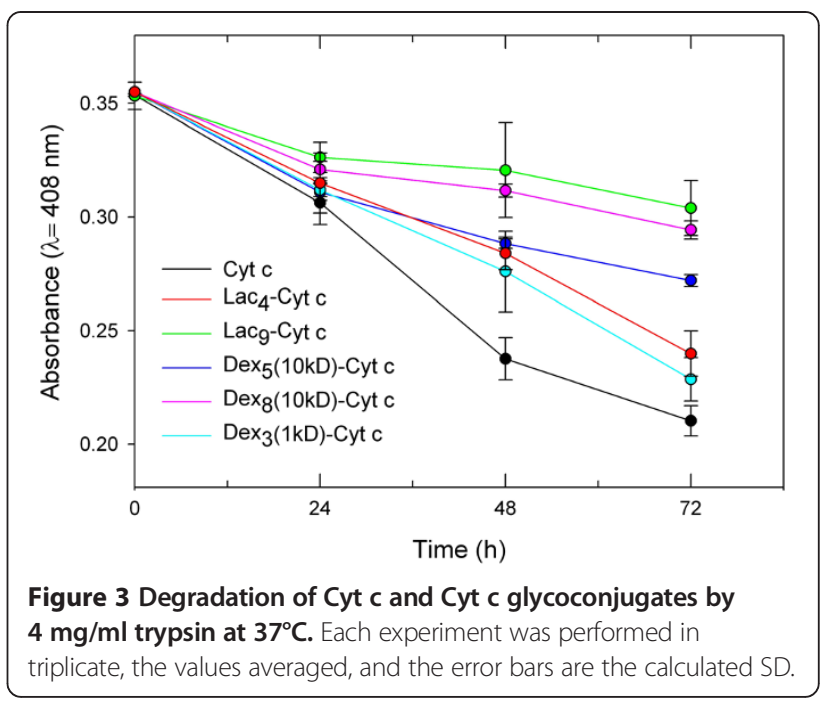

experiment also provides some insight into the effect of glycosylation on Cyt c structural dynamics or compactness of the folded state. The $\mathrm{CD}$ experiments revealed that Cyt c was not packed more densely as the result of glycosylation (Figure 2B) in contrast to what we have found for some other proteins [52-57]. This is not unexpected since Cyt $\mathrm{c}$ is intrinsically already very stable and not dynamic. The lack of an effect of sugars to stabilize Cyt c by reducing structural dynamics (molecular breathing) against the small molecule $\mathrm{H}_{2} \mathrm{O}_{2}$ is in agreement with the $\mathrm{CD}$ data.

We have previously reported that chemical protein glycosylation was able to reduce moisture-induced aggregation of chymotrypsin under accelerated conditions [73], which is pharmaceutically relevant once vials or formulations of pharmaceutical proteins are exposed to moisture [74]. One has to keep in mind that this phenomenon is not only relevant to the exposure of

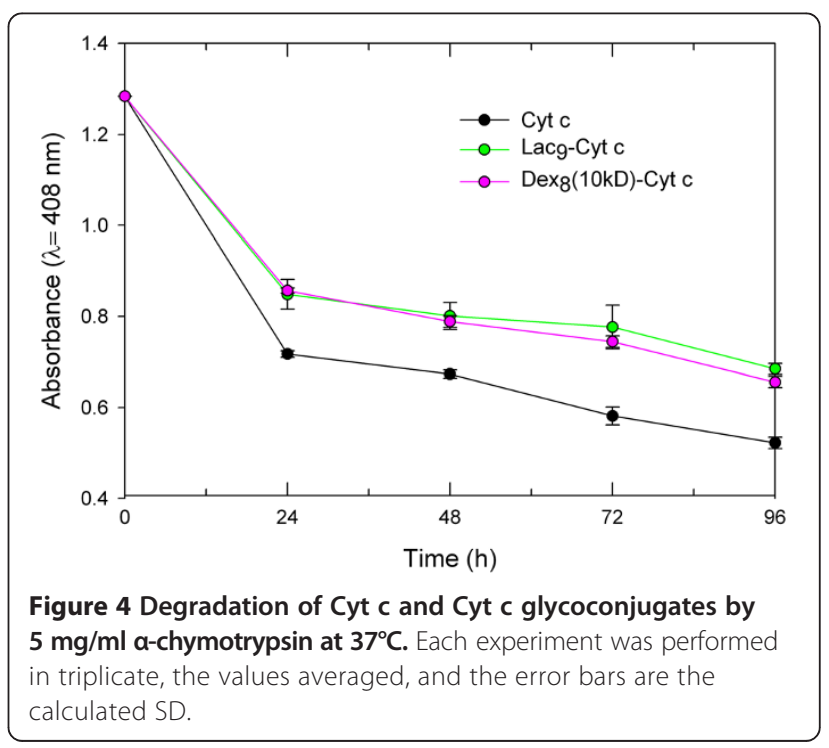


lyophilized proteins to moisture upon opening sealed and dehydrated vials under atmospheric conditions, but also applies to the slow rehydration of dehydrated proteins inside of drug delivery systems [75]. Water frequently cannot penetrate the interior of drug delivery systems that are based on hydrophobic materials (e.g., poly(lactic-co-glycolic) acid) and encapsulated proteins are rehydrated slowly upon polymer swelling and degradation.

Cyt $\mathrm{c}$ and Cyt $\mathrm{c}$ glycoconjugates were exposed to accelerated storage conditions of high humidity $(75 \%$ relative humidity) (Figure 5) and high temperature $\left(50^{\circ} \mathrm{C}\right)$ (Figure 6) for $72 \mathrm{~h}$. It is evident that glycosylation substantially reduced the susceptibility of Cyt $\mathrm{c}$ to the heat and moisture stresses.

The stabilization of Cyt c towards moisture (Figure 5) was related to the amount and size of the glycan attached. The disaccharide lactose had only little effect on improving Cyt c stability at the lowest ratio. Increasing the amount of that glycan attached to Cyt c improved its stability. In contrast, dextran with a $\mathrm{M}_{\mathrm{W}}$ of $10 \mathrm{kD}$ practically completely prevented Cyt c degradation by moisture already when five molecules were bound.

Similarly, denaturation by heat was prevented the more efficiently the more glycan was bound to Cyt c and the larger the sugar entity (Figure 6). Our interpretation for the data is that the Cyt c surface was shielded by the glycans and that this reduced protein-protein interactions which can cause irreversible denaturation events. Regardless of the exact mechanism, it is clear that the $\operatorname{Dex}_{8}(10 \mathrm{kD})$-Cyt $\mathrm{c}$ was the most stable preparation, in particular under elevated temperature conditions.

Finally, we also aimed at assessing the effect of exposure of Cyt c to an organic solvent interface. Such interfaces

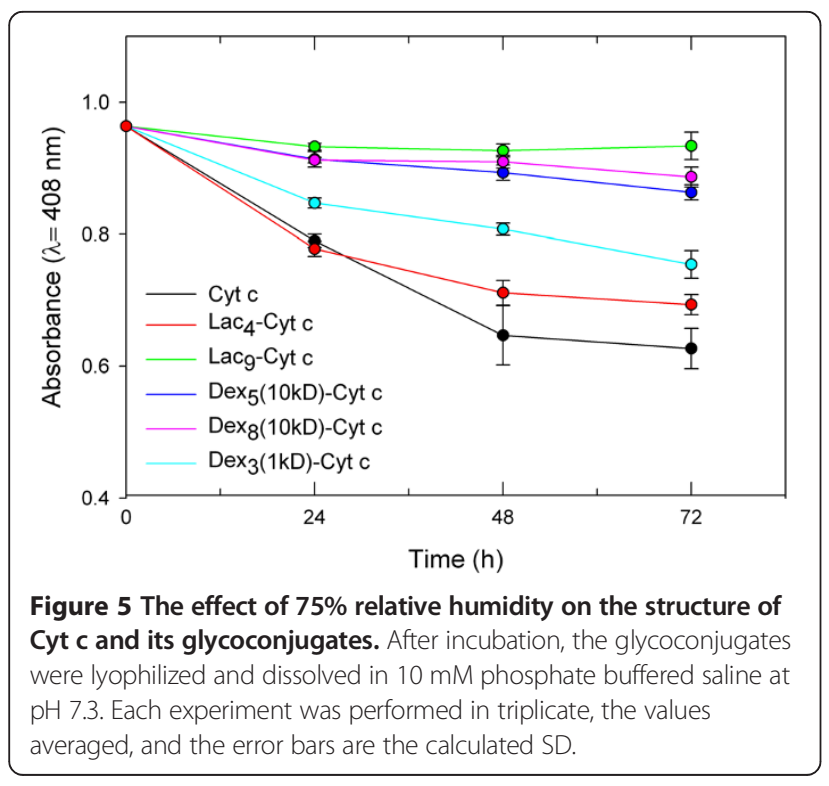

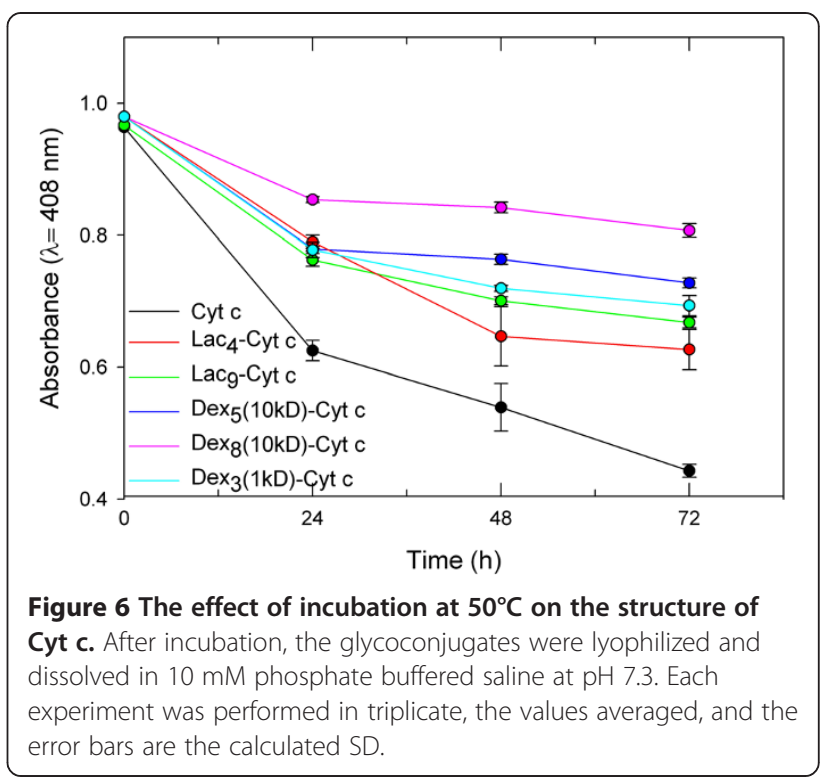

are common when preparing protein nanoparticles by precipitation [76] or upon protein encapsulation into hydrophobic polymers, e.g., by the water-in-oil-in-water double emulsion technique [77]. We selected one representative sample $\left(\operatorname{Dex}_{3}(10 \mathrm{kD})\right.$-Cyt c) and two solvents previously employed in nanoparticle preparation following solvent precipitation protocols, i.e., acetone and acetonitrile [76]. Using various ratios, we found that $1: 2$ and $1: 4$ water-to-acetonitrile volume ratios were sufficient to induce Cyt c precipitation and result in stable suspensions. Next we tested the effect of the protein-solvent interface on the capacity of Cyt c to induce in vitro caspase 3 activation in a cell-free system (Table 2). Therapeutic use of Cyt $\mathrm{c}$ in cancer applications relies on the induction of apoptosis after the protein was delivered to the cytoplasm $[24,26,58]$. The results demonstrate that Cyt c suffered significant activity loss when precipitated with acetonitrile and acetone (Table 2). In contrast, glycosylation prevented inactivation completely for both solvents. We interpret the results as being indicative for the glycan preventing Cyt c - organic solvent interface interactions, which are typically initiated by hydrophobic protein surface patches and driven by entropic effects [78].

While the Cyt c functionality upon contact with the two organic solvents was maintained regardless of the desolvating agent used, SEM images show differences in the particle properties after the precipitation process (Figure 7). SEM images of $\operatorname{Dex}_{3}(1 \mathrm{kD})$-Cyt $\mathrm{c}$ show that the powder particles obtained with both solvents had a spherical shape and that the particle size was in the nanometer range. However, particles obtained by using acetone were smaller and more homogeneous than those obtained with acetonitrile. For drug delivery applications 
Table 2 Results of the capability of Cyt $c$ and $\operatorname{Dex}_{3}(1 \mathrm{kD})$-Cyt $\mathrm{c}$ to activate apoptosis after their exposure to water-organic solvent $(o / w)$ interface conditions

\begin{tabular}{|c|c|c|}
\hline Protein & Desolvating agent & Relative caspase 3 activation ${ }^{\#}(\%)$ \\
\hline \multirow[t]{2}{*}{ Cyt C } & Acetonitrile & $64 \pm 8$ \\
\hline & Acetone & $51 \pm 2$ \\
\hline \multirow[t]{2}{*}{$\operatorname{Dex}_{3}(1 \mathrm{kD})$-Cyt c } & Acetonitrile & $100 \pm 4$ \\
\hline & Acetone & $100 \pm 3$ \\
\hline
\end{tabular}

"The relative activity was calculated with respect to the caspase 3 activation induced by Cyt c/Apaf-1 complex.

using the EPR effect a diameter of $<400 \mathrm{~nm}$ and good homogeneity are desirable [19].

From our data we can surmise that chemical Cyt c glycosylation is a very useful approach to protect the protein from various stresses that are typically associated with pharmaceutical production processes and the delivery. Even though we have not conducted detailed mechanistic studies in this work, the data are consistent with the glycans providing protection in an amount and size dependent manner. The larger the glycan and the more attached to Cyt c, the better the protection. It is likely that the protection afforded is due to a combination of effects, i.e., restriction of the conformational space, reduction of solvent accessible area, and avoiding proteinsolvent hydrogen bonds, as previously suggested by us [52-57] and others [49,62-64].

\section{Conclusions}

Protein instability is a major factor limiting their use in pharmaceutical applications. Herein we explored how the covalent attachment of lactose and dextran via amine-directed linker chemistry affects the stability of Cyt c. Cyt c is a protein with good potential in cancer applications since it can be utilized to induce apoptosis upon intracellular delivery. We show that glycosylation does not negatively affect the capability of Cyt $\mathrm{c}$ to induce apoptosis. Furthermore, glycosylation improves the stability of Cyt c towards many stress factors relevant to the formulation, storage, and delivery of the protein into the cancer tumor microenvironment. We conclude that glycosylation should be a very useful method for improving Cyt c properties in cancer and other pharmaceutical applications.

\section{Methods}

\section{Chemicals}

Cytochrome c from equine heart (EC 232-700-9), dextran from L. mesenteroides (EC 232-6775, average $\mathrm{M}_{\mathrm{w}}=9-11$ $\mathrm{kD}$ ), trypsin from porcine pancreas, $\alpha$-chymotrypsin type II from bovine pancreas, caspase 3 substrate (DEVDpNA), caspase 9 substrate (LEHD-pNa), disuccinimidyl suberate linker, protease inhibitor cocktail, 2,2'-azino-bis (3-ethylbenzothiazoline-6-sulphonic acid) (ABTS), ammonium carbonate, dimethyl sulfoxide (DMSO), methylene chloride, acetone, and acetonitrile (HPLC grade) were from Sigma-Aldrich (St. Louis, MO). Mono-(lactosylamido)-mono-(succinimidyl) suberate (NHS-Lac) and dextran hexanoic acid (Dex-COOH, $\mathrm{M}_{\mathrm{W}}=1 \mathrm{kD}$ ) were from Carbomer (San Diego, CA). Cellulose ester dialysis membranes were from Spectrum (Rancho Dominguez, CA). EDC and NHS were from Proteochem (Denver, CO). A caspase-3 activity assay (CaspACE ${ }^{\mathrm{Tm}}$ assay) was purchased from Promega (Madison, WI). HeLa cells, sera and culture media were purchased from the American Type Culture Collection (Manassas, VA). All other chemicals were from various commercial suppliers and were of analytical grade.
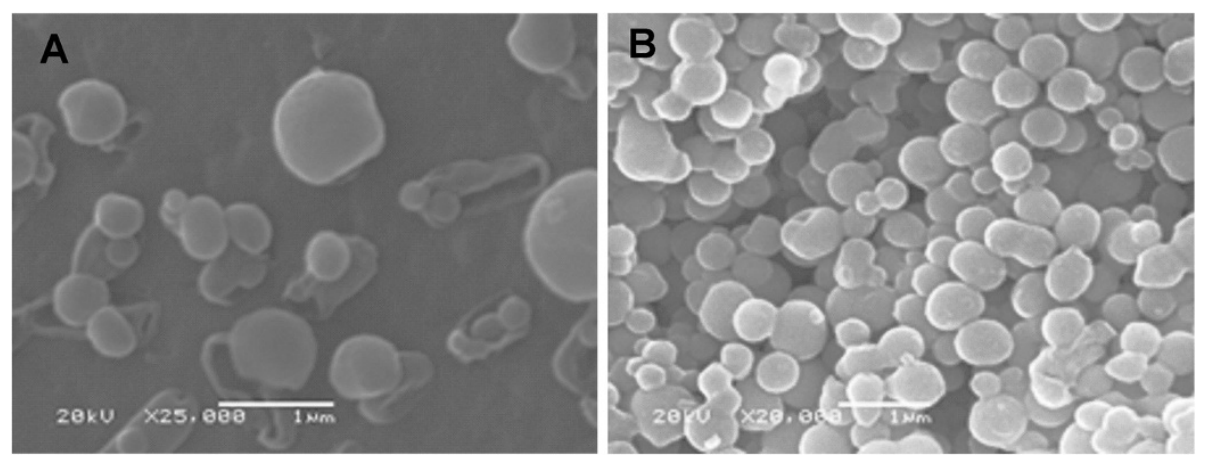

Figure 7 Scanning electron microscopy (SEM) images of lyophilized $\operatorname{Dex}_{3}(1 \mathrm{kD})$-Cyt c after the precipitation via solvent displacement with (A) acetonitrile and (B) acetone as desolvating agent. 


\section{Amine-reactive functionalization of $10 \mathrm{kD}$ dextran}

The synthesis of amine-reactive glycans was performed as previously established [52,78-80]. Synthesis of mono(dextranamido)-mono-(succinimidyl) suberate (NHSDex, $10 \mathrm{kD}$ ) consisted of selective amination followed by succinnylation. Dextran $(10 \mathrm{kD})(10.0 \mathrm{~g}, 1.0 \mathrm{mmol})$ and ammonium carbonate $(2.0 \mathrm{~g}, 21.74 \mathrm{mmol})$ in nanopure water $(50.0 \mathrm{ml})$ were stirred at $10^{\circ} \mathrm{C}$ for five days. Afterwards ammonium carbonate was removed by dialysis $\left(\mathrm{M}_{\mathrm{W}}\right.$ cut-off $\left.100 \mathrm{D}\right)$ for $48 \mathrm{~h}$ and the solution was lyophilized to afford 1-amino-dextran. To achieve dextran succinnylation, 1-hydroxy benzotriazole $(0.675 \mathrm{~g}, 5.0 \mathrm{mmol})$ and disuccinimidyl suberate $(1.841 \mathrm{~g}, 5.0 \mathrm{mmol})$ were dissolved in DMSO $(60 \mathrm{ml})$ and heated to $80^{\circ} \mathrm{C}$ for $5 \mathrm{~min}$. After cooling, 1-amino-dextran $(5.0 \mathrm{~g}, 0.5 \mathrm{mmol})$ was added and the reaction maintained at $20^{\circ} \mathrm{C}$ for $24 \mathrm{~h}$. The product was precipitated by addition of $\mathrm{CH}_{2} \mathrm{Cl}_{2}(200 \mathrm{ml})$ pelleted by centrifugation $(1,500 \mathrm{rpm})$ at $4{ }^{\circ} \mathrm{C}$ for $15 \mathrm{~min}$. The resulting white precipitate was lyophilized to afford NHS-Dex $(10 \mathrm{kD})$ in quantitative yield.

\section{Amine-reactive functionalization of Dex- $\mathrm{COOH}$}

Dex-COOH is chemically reactive to carbodiimides. Thus, EDC/NHS crosslinking chemistry was used to form the amine reactive NHS-Dex $1 \mathrm{kD}$ to directly couple it to primary amines of Cyt c as described [81]. Briefly, $1 \mathrm{mg} / \mathrm{ml}$ of Dex-COOH in 2- (N-morpholino) ethanesulfonic acid (MES) buffer was reacted with $2 \mathrm{mM}$ of EDC and $4 \mathrm{mM}$ of NHS for 20 minutes at room temperature. Immediately, the glycosylation reaction was started for Dex (1kD)-Cyt c glycoconjugate.

\section{Glycosylation of Cyt c}

Cyt c glycoconjugates were prepared by chemical glycosylation with succinimidyl-activated glycans (NHS-Dex $(10 \mathrm{kD})$, NHS-Dex $(1 \mathrm{kD})$ and NHS-Lac) as described by us in detail previously [53]. Briefly, $100 \mathrm{mg}$ of Cyt c was dissolved in $20 \mathrm{ml}$ of $100 \mathrm{mM}$ phosphate buffer with $20 \mathrm{mM} \mathrm{NaCl}$ at pH 7.4. To achieve glycoconjugates with two levels of glycosylation, Cyt c solutions were reacted with an excess of 5 and 10 moles of NHS-Lac, an excess of 8 and 15 moles of NHS-Dex $(10 \mathrm{kD})$ and an excess of 5 moles of NHS-Dex $(1 \mathrm{kD})$. The reaction was performed for $1 \mathrm{~h}$ at room temperature under gentle stirring. Unbound glycans were removed by dialyzing thrice against nanopure water at $4^{\circ} \mathrm{C}$ for $48 \mathrm{~h}$. After the dialysis, all the glycoconjugates were lyophilized for $48 \mathrm{~h}$ and then stored at $-20^{\circ} \mathrm{C}$. The extent of modification was determined by TNBSA colorimetric assay as described $[82,83]$.

\section{Circular dichroism (CD) spectroscopy}

CD spectra were recorded using an OLIS DSM-10 UVvis $\mathrm{CD}$ spectrometer at $21^{\circ} \mathrm{C}$. Cyt $\mathrm{c}$ and Cyt c glycoconjugates were dissolved in $20 \mathrm{mM}$ PBS at $\mathrm{pH}$ 7.4. CD spectra were acquired from 200 to $260 \mathrm{~nm}$ (secondary structure), 260 to $320 \mathrm{~nm}$ (tertiary structure) and 380 to $450 \mathrm{~nm}$ (Soret region) at a concentration of $0.6 \mathrm{mg} / \mathrm{ml}$ using quartz cuvettes of 0.2 to $10 \mathrm{~mm}$ path lengths. Each spectrum was obtained by averaging six scans. Spectra of buffer blanks were measured prior to the samples and subtracted digitally using the software supplied with the instrument.

\section{Peroxidase pseudo-activity assay}

The peroxidase-like activity of Cyt c was measured as described [84]. Briefly, the reaction was followed photometrically at $415 \mathrm{~nm}$ using $0.25 \mathrm{ml}$ of $0.01 \mathrm{mg} / \mathrm{ml}$ Cyt c or Cyt c glycoconjugates, $0.2 \mathrm{ml}$ of $300 \mathrm{mM} \mathrm{H}_{2} \mathrm{O}_{2}$, and $0.55 \mathrm{ml}$ of $0.05 \mathrm{mM}$ ABTS in $20 \mathrm{mM}$ potassium phosphate buffer at $\mathrm{pH}$ 7. In all cases the specific activity $\left(\mathrm{mM}\right.$ of $\mathrm{ABTS}^{+} \mathrm{x} \mathrm{min}^{-1} \times \mathrm{mg}^{-1}$ Cyt c) was calculated. The activity was obtained by plotting the time-dependent absorbance changes $v s$. time. The linear portions of the graphs at less than $10 \%$ substrate conversion were used to obtain the initial velocities $\left(\mathrm{V}_{0}\right)$. The experiments were performed in triplicate, the results averaged and the standard deviations calculated.

\section{Moisture and temperature-induced structural instability}

The study of the effect of moisture and heat on Cyt c integrity during storage was performed as described $[71,85]$. Briefly, $0.60 \mathrm{mg} / \mathrm{ml}$ of Cyt c and Cyt c glycoconjugates in PBS at pH 7.4 (liquid-phase formulation) were exposed to accelerated stress storage conditions. To study moisture-induced instability, Cyt c and its glycoconjugates were incubated in a desiccator over $\mathrm{NaCl}$ salt slush at $20^{\circ} \mathrm{C}$ (which corresponds to $75 \%$ relative humidity) for 24,48 , and $72 \mathrm{~h}$. To study heat- induced instability of Cyt c, the samples were incubated in a heat chamber at $50^{\circ} \mathrm{C}$ for 24,48 , and $72 \mathrm{~h}$. After the desired length of time, the incubated protein samples were removed followed by $20 \mathrm{~min}$ of gentle stirring to ensure dissolution of the samples. The degradation of Cyt $\mathrm{c}$ samples was monitored at $408 \mathrm{~nm}[61,71,72]$. Error bars in the figure are the calculated standard deviations (SD).

\section{Oxidative stress assay}

The rate of Cyt c degradation upon exposure to oxidative stress was monitored as previously described [61,71]. In brief, $200 \mu \mathrm{l}$ of $1.5 \mathrm{mM} \mathrm{H}_{2} \mathrm{O}_{2}$ was added to $1 \mathrm{ml}$ of Cyt c and Cyt c glycoconjugates $(0.2 \mathrm{mg} / \mathrm{ml})$ in $20 \mathrm{mM}$ PBS $\mathrm{pH} 7.4$ at $21^{\circ} \mathrm{C}$. Cyt c degradation was measured by monitoring the rate of the decrease in the Soret band absorbance at $408 \mathrm{~nm}$ after $10 \mathrm{~min}$ of incubation. The degradation rate constant $\left(\mathrm{K}_{\mathrm{d}}\right)$ was calculated from the residual absorption versus time using first order kinetics. The experiments were performed in triplicate, the results averaged and the SD calculated. 


\section{Cell culture}

HeLa cells were maintained in accordance with the ATCC protocol. Briefly, the cells were cultured in minimum essential medium (MEM) containing 1\% L-glutamine, 10\% fetal bovine serum (FBS), and $1 \%$ penicillin in a humidified incubator with $5 \% \mathrm{CO}_{2}$ and $95 \%$ air at $37^{\circ} \mathrm{C}$. All experiments were conducted before cells reached 25 passages. During each passage, cells were washed twice with PBS, detached using trypsin, and resuspended in supplemented MEM.

\section{Cell-free caspase 3 and caspase 9 activity assays}

These assays were adopted from the literature [86]. In brief, HeLa cells were grown to $80 \%$ confluency and harvested as described above (cell culture method). For disruption the cells were suspended in $20 \mathrm{mM} \mathrm{4-(2-}$ hydroxyethyl)-1-piperazineethanesulfonic acid (HEPES) buffer at $\mathrm{pH} 7.5,10 \mathrm{mM} \mathrm{KCl}, 1.5 \mathrm{mM} \mathrm{MgCl}_{2}, 1 \mathrm{mM}$ sodium EDTA, 1 mM sodium EGTA, 1 mM DTT, $250 \mathrm{mM}$ sucrose, and a protease cocktail inhibitors (serine, cysteine, aspartic acid, and metalloprotease inhibitors) $(1 \times)$. The suspended cells were frozen in liquid $\mathrm{N}_{2}$ for $2 \mathrm{~min}$ and thawed in a $37^{\circ} \mathrm{C}$ water bath and the freeze/thaw cycle repeated thrice. The lysate was centrifuged at $10,000 \times \mathrm{g}$ for $20 \mathrm{~min}$ to remove the mitochondria. The protein concentration in the lysate was determined using the Bradford assay [87]. The cell-free reactions were performed in homogenizing buffer in a total volume of $100 \mu \mathrm{L}$. The reaction was initiated by adding $100 \mu \mathrm{g} / \mathrm{ml}$ of Cyt c or Cyt c glycoconjugates to freshly purified cytosol (3 mg/ $\mathrm{ml}$ of proteins). The reaction was incubated at $37^{\circ} \mathrm{C}$ for $150 \mathrm{~min}$. Later, $20 \mu \mathrm{l}$ of the reaction mixtures was withdrawn and added to $78 \mu \mathrm{l}$ of a mixture containing $100 \mathrm{mM}$ HEPES at $\mathrm{pH} 7.5,10 \% \mathrm{w} / \mathrm{v}$ sucrose, $0.1 \% \mathrm{w} / \mathrm{v}$ CHAPS (3-[(3-cholamido-propyl)-dimethylammonio]1-propane-sulfonate), $10 \mathrm{mM}$ DTT, and 2\% v/v DMSO. This mixture was prepared for caspase 3 or caspase 9 assay in two different 96-well plates. Caspase 3 activity was measured using $2 \mu \mathrm{l}$ of the substrate DEVD-pNA $(10 \mathrm{mM})$ and caspase 9 activity using $2 \mu \mathrm{l}$ of the substrate LEHD-pNa $(4 \mathrm{mM})$. The plates were incubated overnight at room temperature and the absorbance at $405 \mathrm{~nm}$ was measured for both assays using a microplate reader (Thermo Scientific Multiscan FC). All measurements were performed in triplicate.

\section{Proteolytic assays}

Protease degradation was performed as described by Reinhardt et al. [88]. In brief for tryptic degradation, $0.16 \mathrm{mg} / \mathrm{ml}$ of Cyt c or Cyt c glycoconjugates in $20 \mathrm{mM}$ Tris- $\mathrm{HCl}$ at $\mathrm{pH} 8$ were gently stirred for $20 \mathrm{~min}$ at $20^{\circ} \mathrm{C}$. Then, $4 \mathrm{mg}$ of trypsin was added to $1 \mathrm{ml}$ of each sample and the mixture incubated at $37^{\circ} \mathrm{C}$ for 24,48 and $72 \mathrm{~h}$. For chymotryptic degradation, $0.79 \mathrm{mg} / \mathrm{ml}$ of Cyt c or Cyt c glycoconjugates in $20 \mathrm{mM}$ Tris- $\mathrm{HCl}$ at $\mathrm{pH} 8$ were gently stirred for $20 \mathrm{~min}$ at $20^{\circ} \mathrm{C}$. Then, $5 \mathrm{mg}$ of chymotrypsin was added to $1 \mathrm{ml}$ of each sample and the mixture incubated at $37^{\circ} \mathrm{C}$ for 24, 48, 72 and $96 \mathrm{~h}$. For both assays, Cyt c degradation was determined by measuring the absorbance at $408 \mathrm{~nm}$ after the incubation times.

\section{Protein precipitation by solvent displacement}

A solvent displacement method similar to that described by us [76] was performed to precipitate Cyt c and obtain nanoparticles. Briefly, $5.0 \mathrm{mg}$ of Cyt c was solvent-precipitated by adding $1.5 \mathrm{ml}$ of acetonitrile to $1 \mathrm{ml}$ of aqueous solution. To precipitate the Dex $(1 \mathrm{kD})$-Cyt c conjugate the concentration of the glycoconjugate was adjusted to $2.5 \mathrm{mg} / \mathrm{ml}$ and the volume ratios to precipitate it with acetonitrile and acetone were $1: 2$ and 1:1, respectively, in this case.

\section{Scanning electron microscopy (SEM)}

SEM of lyophilized Cyt $\mathrm{c}$ and Dex-Cyt c after protein precipitation was performed using a JEOL 5800LV scanning electron microscope at $20 \mathrm{kV}$. The samples were coated with gold for $10 \mathrm{sec}$ using a Denton Vacuum DV-502A.

\section{Additional file}

\section{Additional file 1: The Additional file 1 contains two figures (Figure A1 and Figure A2) and discusses why we argue that chemical glycosylation did not diminish the capability of Cyt $\mathrm{c}$ to activate caspases 3 and 9. Figure A1 shows the effect of $\beta$-mercaptoethanol exposure of $\operatorname{Dex}_{3}(1 \mathrm{kD})$-Cyt $c$ on the far-UV CD, near-UV CD, and heme region $C D$ spectra. Figure $A 2$ shows the crystal structure (1HRC.pdb) of horse heart Cyt c including the solvent-exposed Lys residues.}

\section{Abbreviations}

ABTS: 2,2'-azino-bis(3-ethylbenzothiazoline-6-sulphonic acid); ATCC. American Type Culture Collection; Cyt c: cytochrome c; CD: circular dichroism; Dex: dextran; Dex-COOH: dextran hexanoic acid; EDC ethyl-3-[3-dimethylamino-propyl]carboiimide hydrochloride; EPR: enhanced permeability and retention; FTIR: Fourier-transformed infrared; Lac: lactose; NHS: N-hydroxysuccinimide; NHS-Dex: mono-(dextranamido)-mono(succinimidyl)suberate; NHS-Lac: mono-(lactoseamido)-mono-(succinimidyl) suberate; NMR: nuclear magnetic resonance; PEG: poly(ethylene glycol); SEM: scanning electron microscopy.

\section{Competing interest}

The authors declare that they have no competing interest.

\section{Authors' contribution}

YD carried out all the experimental studies (except protein precipitation by solvent displacement and SEM), contributed to the experimental strategy, analyzed data, and drafted the manuscript. MMC carried out the protein precipitation by solvent displacement and SEM studies, analyzed data, and helped drafting the manuscript. JHR and YM helped in the experimental studies. KG conceived the study, participated in its design and coordination, and finalized the manuscript. All authors read and approved the final manuscript.

\section{Acknowledgements}

This publication was made possible by grant SC1 GM086240 from the National Institute for General Medical Sciences (NIGMS) at the National Institutes of Health $(\mathrm{NIH})$ through the Support of Competitive Research (SCORE) Program. Its contents are solely the responsibility of the authors and do not necessarily represent the official views of NIGMS. YD and MM were supported by fellowships from the NIH Research Initiative for Scientific 
Enhancement (RISE) Program (R25 GM061151) and YD received a fellowship from the Bridge to the Doctorate Program AMP (HRD-0832961) of NSF at the University of Puerto Rico.

Received: 17 March 2014 Accepted: 1 August 2014

Published: 6 August 2014

\section{References}

1. Eklund JW, Trifilio S, Mulcahy MF: Chemotherapy dosing in the setting of liver dysfunction. Oncology 2005, 19:1057-1069.

2. Naidu MU, Ramana GV, Rani PU, Mohan IK, Suman A, Roy P: Chemotherapyinduced and/or radiation therapy-induced oral mucositis - complicating the treatment of cancer. Neoplasia 2004, 6:423-431.

3. Torchilin VP: Targeted pharmaceutical nanocarriers for cancer therapy and imaging. AAPS J 2007, 9:E128-E147.

4. Fan L, Wu H, Zhang H, Li F, Yang TH, Gu CH, Yang Q: Novel super pHsensitive nanoparticles responsive to tumor extracellular pH. Carbohyd Polym 2008, 73:390-400

5. Azarmi S, Roa WH, Lobenberg R: Targeted delivery of nanoparticles for the treatment of lung diseases. Adv Drug Deliv Rev 2008, 60:863-875.

6. Veiseh O, Sun C, Fang C, Bhattarai N, Gunn J, Kievit F, Du K, Pullar B, Lee D, Ellenbogen RG, Olson J, Zhang M: Specific targeting of brain tumors with an optical/magnetic resonance imaging nanoprobe across the blood-brain barrier. Cancer Res 2009, 69:6200-6207.

7. Liu Y, Zhang B, Yan B: Enabling anticancer therapeutics by nanoparticle carriers: the delivery of Paclitaxel. Int J Mol Sci 2011, 12:4395-4413.

8. Almeida JP, Chen AL, Foster A, Drezek R: In vivo biodistribution of nanoparticles. Nanomedicine 2011, 6(5):815-835.

9. Albanese A, Tang PS, Chan WC: The effect of nanoparticle size, shape, and surface chemistry on biological systems. Annu Rev Biomed Eng 2012, 14:1-16.

10. Lu RM, Chen MS, Chang DK, Chiu CY, Lin WC, Yan SL, Wang YP, Kuo YS, Yeh CY, Lo A, Wu HC: Targeted drug delivery systems mediated by a novel peptide in breast cancer therapy and imaging. PLoS One 2013, 8:e66128.

11. Madaan A, Singh P, Awasthi A, Verma R, Singh AT, Jaggi M, Mishra SK, Kulkarni S, Kulkarni H: Efficiency and mechanism of intracellular paclitaxel delivery by novel nanopolymer-based tumor-targeted delivery system, Nanoxel $^{\mathrm{TM}}$. Clin Transl Oncol 2013, 15:26-32.

12. Danhier F, Feron $\mathrm{O}$, Preat $\mathrm{V}$ : To exploit the tumor microenvironment: passive and active tumor targeting of nanocarriers for anti-cancer drug delivery. J Control Release 2010, 148:135-146.

13. Ranganathan R, Madanmohan S, Kesavan A, Baskar G, Krishnamoorthy YR, Santosham R, Ponraju D, Rayala SK, Venkatraman G: Nanomedicine: towards development of patient-friendly drug-delivery systems for oncological applications. Int J Nanomedicine 2012, 7:1043-1060.

14. Morachis JM, Mahmoud EA, Almutairi A: Physical and chemical strategies for therapeutic delivery by using polymeric nanoparticles. Pharmacol Rev 2012, 64:505-519.

15. Stroh M, Zimmer JP, Duda DG, Levchenko TS, Cohen KS, Brown EB, Scadden DT, Torchilin VP, Bawendi MG, Fukumura D, Jain RK: Quantum dots spectrally distinguish multiple species within the tumor milieu in vivo. Nat Med 2005, 11:678-682

16. Shan X, Liu C, Yuan Y, Xu F, Tao X, Sheng Y, Zhou H: In vitro macrophage uptake and in vivo biodistribution of long-circulation nanoparticles with poly(ethylene-glycol)-modified PLA (BAB type) triblock copolymer. Colloids Surf B Biointerfaces 2009, 72:303-311.

17. Carter PJ, Senter PD: Antibody-drug conjugates for cancer therapy. Cancer J 2008, 14:154-169

18. Wang Z, Chui WK, Ho PC: Nanoparticulate delivery system targeted to tumor neovasculature for combined anticancer and antiangiogenesis therapy. Pharm Res 2011, 28:585-596.

19. Acharya S, Sahoo SK: PLGA nanoparticles containing various anticancer agents and tumour delivery by EPR effect. Adv Drug Deliv Rev 2011, 63:170-183.

20. Wong C, Stylianopoulos T, Cui J, Martin J, Chauhan VP, Jiang W, Popovic Z, Jain RK, Bawendi MG, Fukumura D: Multistage nanoparticle delivery system for deep penetration into tumor tissue. Proc Natl Acad Sci U S A 2011, 108:2426-2431.

21. Zhang G, Zeng X, Li P: Nanomaterials in cancer-therapy drug delivery system. J Biomed Nanotechnol 2013, 9:741-750.
22. Caraglia M, Marra M, Misso G, Lamberti M, Salzano G, De Rosa G Abbruzzese A: Tumour-specific uptake of anti-cancer drugs: the future is here. Curr Drug Metab 2012, 13:4-21.

23. Hu CM, Aryal S, Zhang L: Nanoparticle-assisted combination therapies for effective cancer treatment. Ther Deliv 2010, 1:323-334.

24. Green DR: Apoptotic pathways: ten minutes to dead. Cell 2005, 121(5):671-674.

25. Kazi A, Sun J, Doi K, Sung SS, Takahashi Y, Yin H, Rodriguez JM, Becerril Berndt N, Hamilton AD, Wang HG, Sebti SM: The BH3 alpha-helical mimic $\mathrm{BH} 3-\mathrm{M} 6$ disrupts $\mathrm{BCl}-\mathrm{X}(\mathrm{L}), \mathrm{BCl}-2$, and $\mathrm{MCL}-1$ protein-protein interactions with Bax, Bak, Bad, or Bim and induces apoptosis in a Bax- and Bim-dependent manner. J Biol Chem 2011, 286:9382-9392.

26. Dejean LM, Martínez-Caballero S, Kinnally KW: Is MAC the knife that cuts cytochrome c from mitochondria during apoptosis? Cell Death Differ 2006, 13:1387-1395

27. Czabotar PE, Colman PM, Huang DC: Bax activation by Bim? Cell Death Differ 2009, 16:1187-1191.

28. Kuwana T, Bouchier-Hayes L, Chipuk JE, Bonzon C, Sullivan BA, Green DR, Newmeyer DD: $\mathrm{BH} 3$ domains of $\mathrm{BH} 3$-only proteins differentially regulate Bax-mediated mitochondrial membrane permeabilization both directly and indirectly. Mol Cell 2005, 17:525-535.

29. Chu ZL, Pio F, Xie Z, Welsh K, Krajewska M, Krajewski S, Godzik A, Reed JC: A novel enhancer of the Apaf1 apoptosome involved in cytochrome c-dependent caspase activation and apoptosis. J Biol Chem 2001, 276:9239-9245.

30. Santra S, Kaittanis C, Pérez JM: Cytochrome c encapsulating theranostic nanoparticles: a novel bifunctional system for targeted delivery of therapeutic membrane-impermeable proteins to tumors and imaging of cancer therapy. Mol Pharm 2010, 7:1209-1222.

31. Slowing II, Trewyn BG, Lin VS: Mesoporous silica nanoparticles for intracellular delivery of membrane-impermeable proteins. J Am Chem Soc 2007, 129:8845-8849.

32. Kim SK, Foote MB, Huang L: The targeted intracellular delivery of cytochrome $\mathrm{c}$ protein to tumors using lipid-apolipoprotein nanoparticles. Biomaterials 2012, 33:3959-3966.

33. Maeda H: Macromolecular therapeutics in cancer treatment: the EPR effect and beyond. I Control Release 2012, 164:138-144.

34. Sahay G, Alakhova DY, Kabanov AV: Endocytosis of nanomedicines. J Control Release 2010, 145:182-195.

35. Schroeder A, Heller DA, Winslow MM, Dahlman JE, Pratt GW, Langer R, Jacks T, Anderson DG: Treating metastatic cancer with nanotechnology. Nat Rev Cancer 2012, 12:39-50

36. Dano K, Behrendt N, Hoyer-Hansen G, Johnsen M, Lund LR, Ploug M, Romer J: Plasminogen activation and cancer. Thromb Haemost 2005, 93:676-681.

37. Vázquez E, Corchero JL, Villaverde A: Post-production protein stability: trouble beyond the cell factory. Microbial Cell Fact 2011, 10:60

38. Jorgensen L, Hostrup S, Moeller EH, Grohganz H: Recent trends in stabilising peptides and proteins in pharmaceutical formulation considerations in the choice of excipients. Expert Opin Drug Deliv 2009, 6:1219-1230.

39. Murphy BM, Swarts S, Mueller BM, van der Geer P, Manning MC, Fitchmun Ml: Protein instability following transport or storage on dry ice. Nat Methods 2013, 10:278-279

40. Patel J, Kothari R, Tunga R, Ritter NM, Tunga BS: Stability considerations for biopharmaceuticals, part 1. BioProcess Int 2011, 9:20-31.

41. Singh SK, Kolhe P, Wang W, Nema S: Large-scale freezing of biologics-a practitioner's review, part one: fundamental aspects. BioProcess Int 2009, 7:32-44.

42. Brown LR: Commercial challenges of protein drug delivery. Expert Opin Drug Deliv 2005, 2:29-42.

43. Elnashar MM: The Art of Immobilization Using Biopolymers, Biomaterials and Nano biotechnology. In Biotechnology of Biopolymers. Volume 1. Intech Publisher; 2011.

44. Valo H, Kovalainen M, Laaksonen P, Hakkinen M, Auriola S, Peltonen L, Linder M, Jarvinen K, Hirvonen J, Laaksonen T: Immobilization of proteincoated drug nanoparticles in nanofibrillar cellulose matrices-enhanced stability and release. J Control Release 2011, 156:390-397.

45. Méndez J, Monteagudo A, Griebenow K: Stimulus-responsive controlled release system by covalent immobilization of an enzyme into mesoporous silica nanoparticles. Bioconjug Chem 2012, 23:698-704. 
46. Méndez J, Morales-Cruz M, Delgado Y, Figueroa CM, Orellano EA, Monteagudo A, Griebenow K: Delivery of chemically glycosylated cytochrome c immobilized in mesoporous silica nanoparticles induces apoptosis in HeLa cancer cells. Mol Pharm 2014, 11:102-111.

47. Veronese FM, Pasut G: PEGylation, successful approach to drug delivery. Drug Discov Today 2005, 10:1451-1458.

48. Rodríguez-Martínez JA, Rivera-Rivera I, Solá RJ, Griebenow K: Enzymatic activity and thermal stability of PEG-alpha-chymotrypsin conjugates. Biotechnol Lett 2009, 31:883-887.

49. Knop K, Hoogenboom R, Fischer D, Schubert US: Poly(ethylene glycol) in drug delivery: pros and cons as well as potential alternatives. Angew Chem Int Ed Engl 2010, 49:6288-6308.

50. Elliott S, Lorenzini T, Asher S, Aoki K, Brankow D, Buck L, Busse L, Chang D, Fuller J, Grant J, Hernday N, Hokum M, Hu S, Knudten A, Levin N, Komorowski R, Martin F, Navarro R, Osslund T: Rogers, G, Rogers, N, Trail G, Egrie J: Enhancement of therapeutic protein in vivo activities through glycoengineering. Nat Biotechnol 2003, 21:414-421.

51. Leader B, Baca QJ, Golan DE: Protein therapeutics: a summary and pharmacological classification. Nat Rev Drug Discov 2008, 7:21-39.

52. Solá RJ, Al-Azzam W, Griebenow K: Engineering of protein thermodynamic, kinetic, and colloidal stability: chemical glycosylation with monofunctionally activated glycans. Biotechnol Bioeng 2006, 94:1072-1079.

53. Solá RJ, Griebenow K: Influence of modulated structural dynamics on the kinetics of alpha-chymotrypsin catalysis. Insights through chemical glycosylation, molecular dynamics and domain motion analysis. FEBS J 2006, 273:5303-5319.

54. Solá RJ, Griebenow K: Chemical glycosylation: new insights on the interrelation between protein structural mobility, thermodynamic stability, and catalysis. FEBS Lett 2006, 580:1685-1690.

55. Solá RJ, Griebenow K: Effects of glycosylation on the stability of protein pharmaceuticals. J Pharm Sci 2009, 98:1223-1245.

56. Pagán M, Solá RJ, Griebenow K: On the role of protein structural dynamics in the catalytic activity and thermostability of serine protease subtilisin Carlsberg. Biotechnol Bioeng 2009, 103:77-84.

57. Solá RJ, Rodríguez-Martínez JA, Griebenow K: Modulation of protein biophysical properties by chemical glycosylation: biochemical insights and biomedical implications. Cell Mol Life Sci 2007, 64:2133-2152.

58. Bratton SB, Salvesen GS: Regulation of the Apaf-1-caspase-9 apoptosome. J Cell Sci 2010, 123:3209-3214.

59. Olteanu A, Patel CN, Dedmon MM, Kennedy S, Linhoff MW, Minder CM, Potts PR, Deshmukh M, Pielak GJ: Stability and apoptotic activity of recombinant human cytochrome c. Biochem Biophys Res Commun 2003, 312:733-740.

60. Budihardjo I, Oliver H, Lutter M, Luo X, Wang X: Biochemical pathways of caspase activation during apoptosis. Annu Rev Cell Dev Biol 1999, 15:269-290.

61. Liu Z, Lin H, Ye S, Liu QY, Meng Z, Zhang CM, Xia Y, Margoliash E, Rao Z, Liu XJ: Remarkably high activities of testicular cytochrome $\mathrm{c}$ in destroying reactive oxygen species and in triggering apoptosis. Proc Natl Acad SCl US A 2006, 103:8965-8970.

62. Dwek RA: Glycobiology: toward understanding the function of sugars. Chem Rev 1996, 96:683-720.

63. Wyss DF, Wagner G: The structural role of sugars in glycoproteins. Curr Opin Biotechnol 1996, 7:409-416.

64. Wormald MR, Dwek RA: Glycoproteins: glycan presentation and protein-fold stability. Structure 1999, 7:R155-R160.

65. Palmieri B, Sblendorio V: Oxidative stress detection: what for? Part II. Eur Rev Med Pharmacol Sci 2007, 11:27-54.

66. Chen JM, Ferec C: Genes, cloned CDNAs, and proteins of human trypsinogens and pancreatitis-associated cationic trypsinogen mutations. Pancreas 2000, 21:57-62

67. de Marzo AM, Platz EA, Sutcliffe S, Xu J, Gronberg H, Drake CG, Nakai Y, Isaacs WB, Nelson WG: Inflammation in prostate carcinogenesis. Nat Rev Cancer 2007, 7:256-269.

68. Almholt K, Lund LR, Rygaard J, Nielsen BS, Dano K, Romer J, Johnsen M: Reduced metastasis of transgenic mammary cancer in urokinasedeficient mice. Int J Cancer 2005, 113:525-532

69. Valko M, Rhodes CJ, Moncol J, Izakovic M, Mazur M: Free radicals, metals and antioxidants in oxidative stress-induced cancer. Chem Biol Interact 2006, 160:1-40.
70. Viñas G, Puig T, Porta R: Oxidative stress in patients with cancer: two sides of the same coin. Med Clin 2012, 139:171-175.

71. Villegas JA, Mauk AG, Vázquez-Duhalt R: A cytochrome c variant resistant to heme degradation by hydrogen peroxide. Chem Biol 2000, 7:237-244

72. Florence TM: The degradation of cytochrome $\mathrm{c}$ by hydrogen peroxide. J Inor Biochem 1985, 23:131-141.

73. Flores-Fernández GM, Pagán M, Almenas M, Solá RJ, Griebenow K: Moisture-induced solid state instabilities in a-chymotrysin and their reduction through chemical glycosylation. BMC Biotechnol 2010, 10:57.

74. Schiffter HA: 5.41 - Pharmaceutical Proteins - Structure, Stability, and Formulation. In Comprehensive Biotechnology. Volumen 5. 2nd edition. Edited by Moo-Young M. Burlington: Academic Press; 2011:521-541.

75. $\mathrm{Yu} \mathrm{J}$, Anchordoquy TJ: Effects of moisture content on the storage stability of dried lipoplex formulations. J Pharm Sci 2009, 98:3278-3289.

76. Morales-Cruz M, Flores-Fernández GM, Orellano EA, Rodríguez-Martínez JA Ruíz M, Griebenow K: Two-step nanoprecipitation for the production of protein-loaded PLGA nanospheres. Results Pharma Sci 2012, 2:79-85.

77. Bilati U, Allemann E, Doelker E: Nanoprecipitation versus emulsion-based techniques for the encapsulation of proteins into biodegradable nanoparticles and process-related stability issues. AAPS PharmSciTech 2005, 6:E594-E604

78. Khabiri M, Minofar B, Brezovsky J, Damborsky J, Ettrich R: Interaction of organic solvents with protein structures at protein-solvent interface. J Mol Model 2013, 19:4701-4711.

79. Vetter D, Gallop MA: Strategies for the synthesis and screening of glycoconjugates. 1. A library of glycosylamines. Bioconj Chem 1995, 6:316-318.

80. Vetter D, Tate EM, Gallop MA: Strategies for the synthesis and screening of glycoconjugates. 2. Covalent immobilization for flow cytometry. Bioconj Chem 1995, 6(3):319-322.

81. Grabarek Z, Gergely J: Zero-length crosslinking procedure with the use of active esters. Anal Biochem 1990, 185:131-135.

82. Castellanos IJ, Al-Azzam W, Griebenow K: Effect of the covalent modification with poly(ethylene glycol) on alpha-chymotrypsin stability upon encapsulation in poly(lactic-co-glycolic) microspheres. J Pharm Sci 2005, 94:327-340.

83. Habeeb AF: Determination of free amino groups in proteins by trinitrobenzenesulfonic acid. Anal Biochem 1966, 14:328-336.

84. Kim SS, Choi SY, Park JH, Lee DJ: Regulation of the activity of Korean radish cationic peroxidase promoter during dedifferentiation and differentiation. Plant Physiol Biochem 2004, 42(10):763-772.

85. Flores-Fernández GM, Solá RJ, Griebenow K: The relation between moisture-induced aggregation and structural changes in lyophilized insulin. J Pharm Pharmacol 2009, 61:1555-1561.

86. Chandra D, Tang DG: Detection of apoptosis in cell-free systems. Methods Mol Biol 2009, 559:65-75.

87. Bradford MM: A rapid and sensitive method for the quantitation of microgram quantities of protein utilizing the principle of protein-dye binding. Anal Biochem 1976, 72:248-254.

88. Reinhardt DP, Ono RN, Sakai LY: Calcium stabilizes fibrillin-1 against proteolytic degradation. J Biol Chem 1997, 272:1231-1236.

\section{doi:10.1186/1471-2091-15-16}

Cite this article as: Delgado et al:: Chemical glycosylation of cytochrome c improves physical and chemical protein stability. BMC Biochemistry 2014 15:16. 